\title{
ゴルフのパッティングについての生理心理学的検討
}

\author{
松田 俊 ${ }^{11}$ 武 良 徹 文 ${ }^{11}$ \\ 矢野直 彦2)*) 柿木昇 治2)
}

\section{Psychophysiological processes during golf putting}

\author{
Takashi Matsuda ${ }^{1}$, Tetsufumi Mura ${ }^{1}$, Naohiko Yano ${ }^{2 *}$ and Shoji Kakigi ${ }^{2}$
}

\begin{abstract}
The aim of this study was to investigate the psychophysiological processing during putting. Eight athletes were recruited as subjects from a university golf club and given 100 trials of putting a ball to a hole, which was placed $200 \mathrm{~cm}$ away from the ball position. EEG was recorded during the performance from $\mathrm{C} z$ site with $5.0 \mathrm{sec}$ time constant. Trials were divided into two categories according to the alternative judgements that were made immediately after each putt; one was a feeling of success of putting and the other was a feeling of failure. The averaged readiness potential for the feeling-of-failure trials was larger than that for the feeling-of-success trails. However, the estimated readiness potential component for the feeling-of-failure trials, which was obtained by the principal component analysis, was not larger than that for the feeling-of-success traials. Moreover, for the feeling-of-failure trials, two estimated readiness potentials and motor potentials were obtained. These results suggest that two psychological processes contribute the subjective feeling of failure in putting while only one psychological process is involved in the feeling of success in putting.
\end{abstract}

Key words: golf, putting, readiness potential

(Japan J. Phys. Educ., 36: 263-270, December, 1991.)

キーワード：コルフ,パッティンク，䇲满西位

緒

運動技能の学習に関する研究において，身体 活動を構成している筋力, 正確さ, タイミング 等の諸要因をパフォーマンス・スコアによって 明らかにすることがでさる。また，その学習の 内容を分析する研究としては，運動や動作その わのの分析と運動や動作の学習過程を分析する 方法がとられている。
運動学習の過程を考えるとき，学習を行動の 変化としての側面からとらえて，そこにみられ る現象的法則性を調べようとするのが一般的で ある.しかし，学習は行動的事象であるだけで なく同時に解剖学的, 生理学的あるいは生化学 的な物質的事象である。したがって，運動学習 に対応して生体内でどのような生理学的過程が 生じているかを明らかにする必要がある.

このように行動的事象の基盤をなしている生 体内の物質的過程を研究する生理心理学的分野
1）厇島電機大学一般教育学科 干 739-03 広島県広島市安芸区中野 6-20-1

2) 広島道大学人文学部

干 731-31 后島県広島市安佐南区大塚 1717

*)現所属 中国日本電気ソフトウェア株式会社 第二ソフトウェフ開発部

干 732 広島県広島市東区若草町 9-7
1. Hiroshima Denki Institute of Technology, Department of General Education, Nakano, Aki, Hiroshima, (739-03)

2. Hiroshima Shudo University, Department of Humanities, Ohtsuka, Asaminami, Hiroshima (731-31)

* NEC Software Chugoku Ltd., Second Software Development Department, Wakakusachou, Higashi, Hiroshima, (732) 
においては, 近年大脳生理学のめざましい発展 に伴って情報理論を中心とした多くの研究がな されている。

随意運動の中权性制御に関しては, 徽小電極 法による神経生理学の知視的立場と共に, 頭皮 上脳波による巨視的立場からのアプローチが， 特に随意動作の統合化された特性を把握する上 で重要である，後者からの立場では，背景脳波 に関するもの ${ }^{2,8,21)}$ 及び楥電位に関するも の 9,10,12,20)がある.

しかし，背景脳波を指標とした運動程過につ いての研究では，背景脳波と運動学習との間に 明確な関係が認められていない，その原因とし て，背固脳波が運動学習事態にのみ特異的に出 現する現象でなく，日常の活動の中で絶え間な く出現し，変動しているため，心理要因との明 確な関連づけが行われていないことが挙げられ る. 課題遂行中の心理要因を反映する生理指標 としては，むしろ楥電位変動がより鋭敏である と考えられる，運動に関連する楥電位変動とし ては，運動関連電位や CNV (contingent negative variation）などがある.

CNV は前期成分（orienting component）と 後期成分 (expectancy component) から構成さ れており，運動反応を求めた時には後期成分に 準備龟位が重畳していると言われている.CNV は期待や注意を反映する電位として注目を集 め, 運動反応との関係も多く研究されている。 $\mathrm{CNV}$ の陰性電位は早い運動反応時の方が遅い 運動反応時より大であり ${ }^{3)}$ ，ょり大さな陰性変 動は小さな陰性変動に比べ反応潜時が短いとい

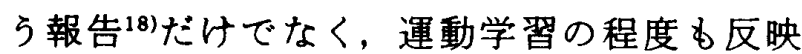
し14)，運動の準備に関連した電位として注目さ れている。

運動関連電位は，随意動作前約 $850 \mathrm{~ms}$ から 生じる緩やかな陰性の電位を N 1 電位（準備電 位), 動作開始の約 $86 \mathrm{~ms}$ 前に始まる陽性電位 を P 1 電位(運動前陽性電位)，同じく動作開始 の䄪 $56 \mathrm{~ms}$ 前から生じる陰性の鋭波を N 2 電 位 (運動電位), 及び動作後の陽性の電位を $\mathrm{P} 2$ 電位と呼んでいる5).
準備電位 (N 1 電位) は，その頭皮上分布が頭 頂部で振幅の優勢がみられ，かなり広汎な部位 から導出されるが，中心野においては動作の対 側中心野で同側に比べて振幅が大きいという特 徵を示す，岩瀬 ${ }^{12)}$ は緩徐な運動の際に準備電位 が急速運動の時より早く立ち上がることを報告 し，よりゆっくり制御された運動を行らには早 くから中枢で運動への準備をする必要があり， その反映が準備電位の出現時期の早遅の相違と なって現れるものと指摘している。このように 準備電位については随意運動の遂行に関する中 权プログラミングとの関連が示唆されている.

動作開始の䄪 $86 \mathrm{~ms}$ 前に始まる陽性電位で ある P 1 電位については，最す不安定な成分で あり，機能的意義についても不明な点が多い。 P 1 電位とそれに続く N 2 電位 (運動電位) 全体 が皮質春髄路の活動を反映するるのとされてお り4，なんらかの運動司令と関連するものと推 察されている6,7).

N 2 (運動電位)に関しては比較的研究が進み いくつかの知見が得られている，N 2 電位の頭 皮上分布については動作の対側中心部に優位に 出現することが一般に指摘されている。

動作後の陽性電位である P 2 電位に関して は，最も古くからその存在が知られており，動 作後の筋感覚求心性フィードベックと中权内 フィードバックを反映する゙といわれている。

以上の研究は生理学的な立場からの基礎研究 が主であるが，CNV と同様に体育心理学的な 研究もあり，緩徐な運動の際に急速運動の時よ り速く立ち上がるといら報告8)や，課題の習得 にしたがい準備電位が大きくなるいう結果を 得ている20). CNV の測定では一般的に $S_{1}-S_{2}$. MR の単純反応時間課題を用いるため課題の制 約が伴うのに対し，準備電位は随意運動事態で 測定されるため自由な運動の検索に適してい る。しかし，準備電位はその測定自由度が高い にもかかわらず，加算平均の困難さやアーティ ファクトの混入しやすさから, 従来の研究では, 指の伸展, 足の屈曲といった局所的な運動課題 が用いられることが多く, 実質的な体育・スポー 
ツ場面での複雑な運動についての研究には, 殆 ど手がつけられていないのが現状である。

そこで, 本研究では，より実際的な運動課題 としてゴルフのパッティングを用い，パッティ ングの準備, 遂行, 完了といった一連の動作時 の緩電位変動について検討する。これまでの準 備電位の研究は, 課題に対する正誤あるいは成 否のない単純な運動課題が用いられることが多 く，たとえ成否があっても結果としての成否を 基準とした分析が行われ，いわゆるその動作遂 行に係わる心理的プロセスを基準とした分析が 行われることは少ない。単純な運動課題におい て，その結果として一義的に成否が決まるよう な事態であれば，結果の成否を基準とした分析 は妥当であろう。しかし，本実験に用いたゴル フのパッティングは, 単純な運動課題と異なり, 運動の完結と結果としての成否（カップインし たか否か）が一致しない事が多く，運動的・心 理的プロセスから見れば動作者が意図したとお りに課題を遂行できたか否かが重要であろう。

そこで，遂行結果ではなく被験者が遂行時に感 じた成功感・失敗感に基づき分類した試行にお。 ける緩電位変動について検索することを目的と する。

方法

\section{1. 被碒者}

男子大学生 8 名 (年齢範囲 19-23 歳, 平均年 齢 20.4 歳)を被験者として用いた。全被験者は 大学ゴルフ部員であった。

\section{2. 反応の測定及ひ記録}

本実験では，生理反応として脳波及び眼球電 位を測定した。脳波は， $\mathrm{Cz}$ を活性電極とし左右 両耳架を結合して不関電極, 右乳様突起を接地 電極として単極導出した。脳波は，生体用プリ アンプ（日本光電社製 AB.622 M)により時定数 5.0 秒で交流増幅した。眼球電位は右眼眼窝上 下縁部に電極を装着し，生体用プリフンプ（日 本光電社製）により時定数 5.0 秒で交流増幅し た。䐉波及び眼球電位の導出には，銀一塩化銀 電極 (ペックマン社製)を用いた。
パッティング試行は，被験者がパターを構え た時点から測定を開始し、パーヘッドが運動 を開始した時点（テークバック開始時点）後 3 秒間測定した。測定したデータは，パターヘッ トの運動開始時点を基点として, 前後 3 秒間を フロッピーディスクに磁気記録した。パター ヘッドの運動開始時点は, パターヘッドから 30 $\mathrm{cm}$ の距離に設置したミラー型ビームセンサ （サンクス社製）により検出した。

導出した脳波及び眼球電位をパーソナルコン ピュータ(NEC 社製 PC-9801 E)内蔵の A/D 変 換ボード（コンテック社製）によって $10 \mathrm{~ms}$ 毎 に A/D 変換し，パーソナルコンピュータに接 続してあるフロッピーディスクに磁気記録し た.

\section{3. 実験条件}

本実験では, 運動課題としてゴルフのパッ ティングを用いた。 パッティングはパット練習 台(縦 $475 \mathrm{~cm}$, 幅 $123 \mathrm{~cm}$, 高さ $21 \mathrm{~cm}$ の水平な 台の上に幅 $93 \mathrm{~cm}$ の人工芝を二重に敷いたも の）の上で行った。パット練習台には，棟習台 の終端から $125 \mathrm{~cm}$ の位置, 被験者から $200 \mathrm{~cm}$ の距離にカップ（直径 $10.8 \mathrm{~cm}$ ) があけてある. ハッティング試行数は 100 試行とした。実験に 使用したパターは，被験者が通常使用している パターであり,ゴルフボールは直径 $4.3 \mathrm{~cm}$, 重 さ $46 \mathrm{~g}$ であった。

パッティングは, 通常の自己のテンポで行い, 疲労を感じれば休想してよいことを教示した。 パッティング試行終了啳, パターヘッドがボー ルに当たった瞬間（インパクト時）にボールが カップに入ると感じたかどらかについて報告を 求めた。被験者は 15-20試行パッティングを行 らと休顋し，パッティングを 100 試行行った。 試行間間隔は 15一30秒であった。

\section{4. 結果の処理及ひ分析}

結果的にボールがカップに入ったか否かにか かわらず，インパクトの瞬間にパッティング動 作が意図通り完結し，ボールが入ると感じたか 否かによる遂行結果予想により成功予想試行と 失敗予想試行に分類した。成功予想試行とは被 


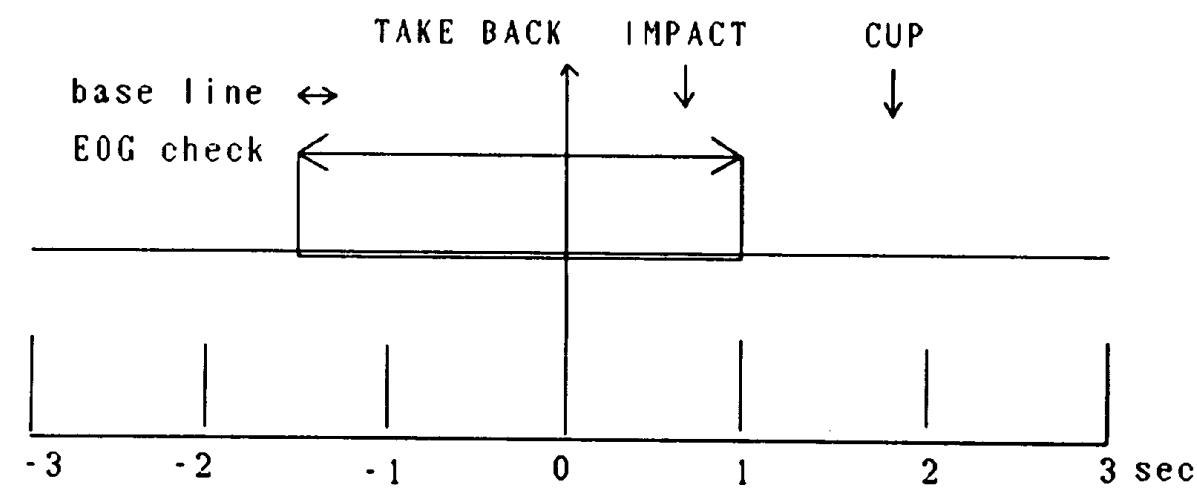

Fig. 1. Analysis period of RPs. RPs were measured from $3 \mathrm{sec}$ before subject's take back to $3 \mathrm{sec}$ after the take back. RPs were analyzed from $1.5 \mathrm{sec}$ before subject's take back to $1.3 \mathrm{sec}$ after the take back to reject EOG potentials as an artifact.

験者自身がきちんとパッティング出来たと感じ た試行であり，失敗予想試行はそれ以外の全て の試行である。成功予想試行と失敗予想試行の 比率は概ね $3: 1$ となった。

緩電位変動の分析においては，テークバック 開始時点を基点とし，基点前 1.5 秒から基点後 1.0 秒までの 2.5 秒間に眼球電位が基準以上変 動した試行は分析の対象から除外した. 基線は, テークバック開始時点前 1.5 秒から基点前 1.3 秒までの 0.2 秒間 ${ }^{11,13-17)}$ の平均とした。緩電位 変動の分析時間を Fig. 1 に示す.

以上の分析後, 遂行結果予想(成功予想試行, 失敗予想試行）別にテークバック開始時点を基 点として加算平均した。眼球電位が混入した試 行を䈣密に除外したため，加算平均に用いた試 行数は 10 試行内外となった。 また, 準備電位の 構成成分を因子分析と重回㷌分析により予測し た ${ }^{15,17)}$. 用いたデータは $20 \mathrm{~ms}$ 毎の脳波の振幅 であり, 総試行数は成功予想試行で 224 , 失敗予 想試行で 82 であった。因子分析は 30 因子抽出 した後に，varimax 回転を行った。その後，平 均波形を従属変数, 各因子を独立変数として重 回㷌分析を行った。これらの分析は世界的に定 評がある SASを用いて行った。

\section{結果}

テークバック開始時点を基点とし，遂行結果 予想 (成功予想試行, 失敗予想試行) 別に加算
平均した波形を Fig. 2 に示す。テークバック開 始前後とも失敗予想試行の電位が成功予想試行 の電位よりも大きくなっている，失敗予想試行 のテークバック開始以前の緩電位は, 成功予想 試行の楥電位に比べて急速に立ち上がっている ことが視察できる。

Fig. 3 はテークバック開始時点を基点とし, テークバック開始前 1.5 秒から開始後 1.0 秒ま での 2.5 秒間の遂行結果予想（成功予想試行, 失敗予想試行）による波形の 0.1 秒間毎の平均 電位を示している，0.1秒毎の区間について成 功予想試行と失敗予想試行の電位の検定を行っ た結果, テークバック開始時点前 0.1 秒と開始 時点前 0.2 秒のポイントで失敗予想試行の電位 が成功予想試行の電位より大きいことが認めら $れ た （$ 開始時点前 0.1 秒: $t=2.63, d f=7$, $p<.05$; 開始時点前 0.2 秒 : $t=3.27, d f=7$, $p<.05)$. また, テークバック開始時点後 0.8 秒 及び開始時点後 0.9 秒の区間においても失敗予 想試行の電位が成功予想試行の電位より大きい ことが認められた（開始時点後 0.8 秒: $t=$ $2.64, d f=7, p<.05$; 開始時点後 0.9 秒 : $t=$ $3.28, d f=7, p<.05)$.

予測された特徵的な成分を Fig. 4 に示した。 成功予想試行に扣いては，テークバック前 $1,460 \mathrm{~ms}$ から大きな陰性楥電位が立ち上がり, 分析区間終了まで継続している。一方，失敗予 想試行ではこれと同じ陰性楥電位が認められる 

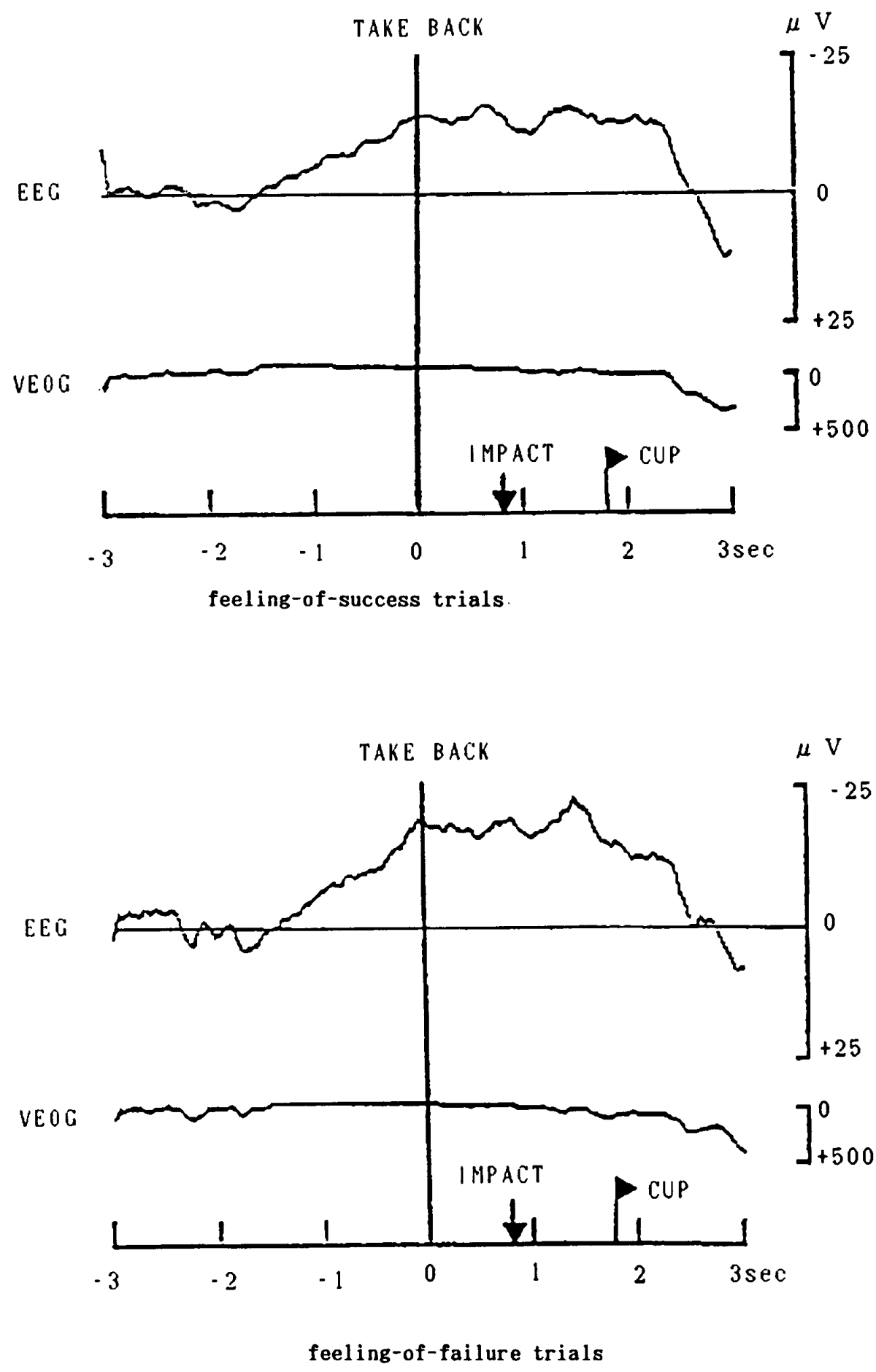

Fig. 2. Grand average of RPS and EOG in the feeling-of-success trials and the feeling-of-failure trials.

が，成功予想試行と比較すると小さい。また， テークバック前 $1,340 \mathrm{~ms}$ から小さな陰性緩電 位が立ち上がり,テークバック前 $720 \mathrm{~ms}$ ピークとして以後減少している。運動電位と思 われるテークバック前後の陰性緩電位は成功予
想試行ではテークバック前 $60 \mathrm{~ms}$ をピークと して小さく現れているが，失敗予想試行では テークバック前 $100 \mathrm{~ms}$ をピークとする大きな 電位と, テークバック時をピークとする中程度 の電位の 2 つの成分が認められた。 


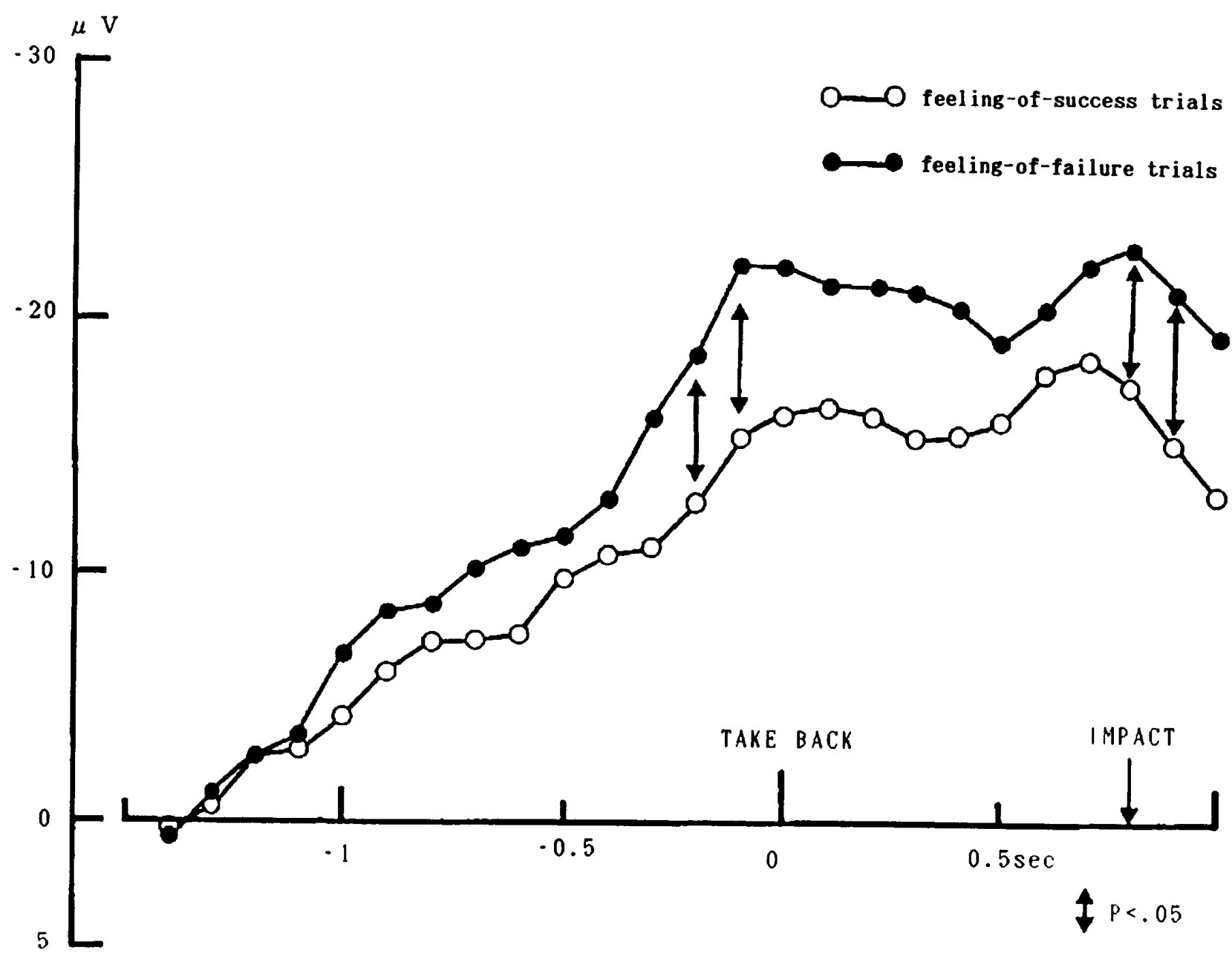

Fig. 3. Mean amplitudes of RPs in the every $100 \mathrm{msec}$ period and the results of $\mathrm{t}$-test.

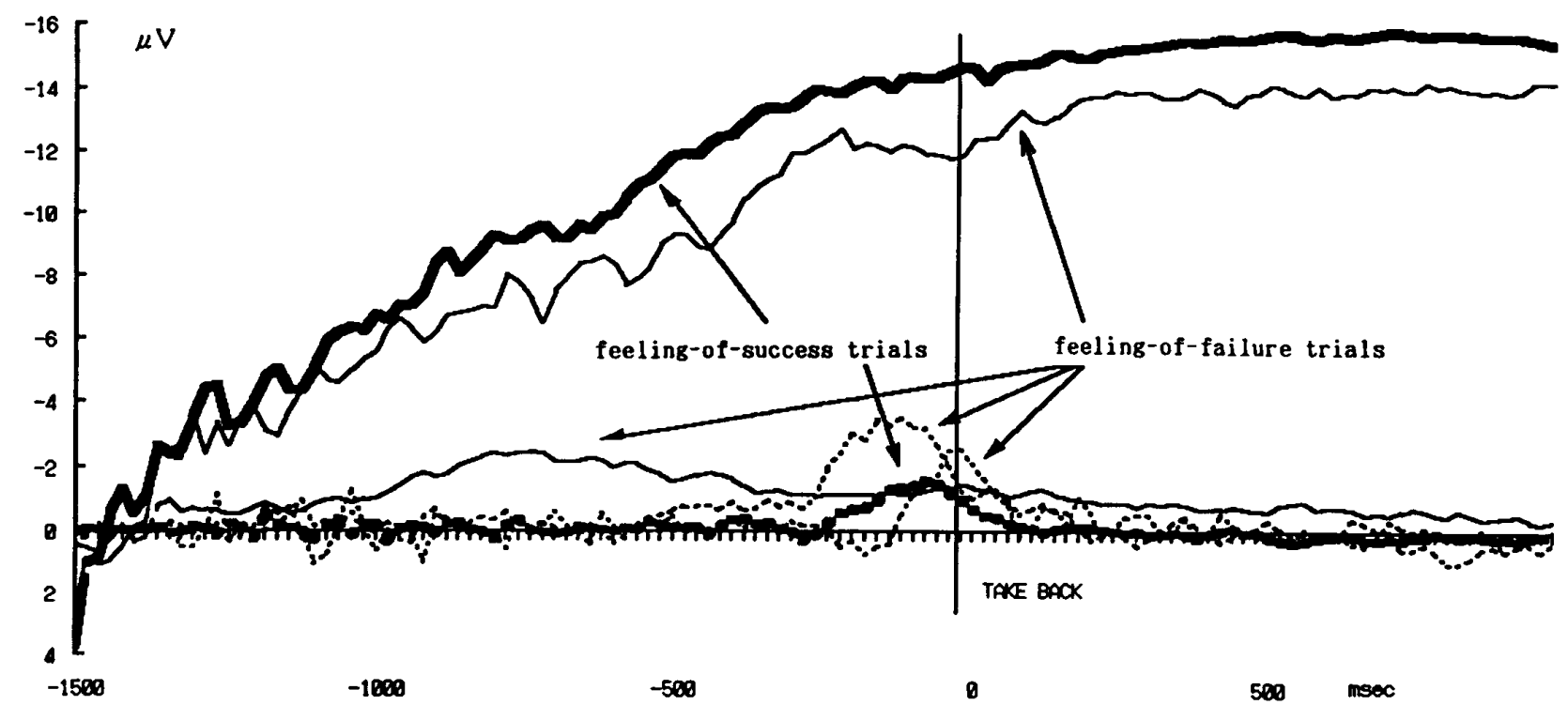

Fig. 4. Wave forms of estimated factors of RPs in the feeling-of-success trials (bold) and the feeling-of failure trials (thin). 


\section{考察}

今回のパッティング動作により得られた隼備 電位の波形は一般的な準備䉓位と比較し波形が 大きく異なる。

まず第一に, 陰性電位の生起が相当早い時期 から生起している。これはハッッティング動作が 緩徐な運動であったためと推察される12).

第二に, 運動開始前後に P 2 が認められず, 運 動終了後もカップにボールが届くまで陰性電位 が持続して，その復帰も緩やかである。これは, 一つにはパッティング動作がテークバック開始 からインパクトとてフォロースルーと比較的 長期に渡る一連の運動であった為であろう。こ の様な継続時間の長い運動では㓌性電位の基線 への復帰が達れることはタイピングを用いた研 究14でも報告されている。また, 動作終了後も結 果の成否を被験者が認知するまでに時間がある ため完了感13.16)を得る時期が遅れた事から陰性 電位の復帰の抑制が生じたものと考兄られる。 このことは準備電位す CNV と同様に期待など の心理過程を反映する，あるいは今回の波形に は期待波が重畳していることを示唆するもので あろう。

第三に，得られた陰性電位の大きさが従来の 研究と比較し非常に大さい。これは, 眼球電位 のアーティファクトは単密に除いているので他 の要因と思われる，従来の研究で用いられた課 題は被験者にとって課題への興味や関心，すな わち課題自体への関与度が低く，また随意運動 とは言いながら，それは運動開始が随意である のみで, 被験者の置かれた状態から考えれば実 験室における強制運動であり, 能動的な随意運 動とは言いがたい，そのため，運動自体に対す る随意性に差がありまた運動の開始前におけ る集中度にも差があった為であろう。今回の パッティングは実験室における多数回の測定で あり,実際のゲームに抢ける状態とは程遠いが， キー押しやレバー引きに比較すれば，被験者の 主体性, 随意性や集中度は比較にならない。 た，P 300 に打いても被験者の関与度が電位の
大きさに影響を与える報告 ${ }^{11}$ むある事から被験 者の課題に対する関わり方が影響した可能性も 考えられる。

次に, 成功予想試行と失敗予想試行を比較し た場合，平均波形で見る範囲では失敗予想試行 が成功予想試行よりも大きな陰性電位を示して いる，しかし，その成分を分離，予測してみる とまったく異なるといら興味ある結果が得られ た. 失敗予想試行に批いては準備電位と運動電 位にそれぞれ2つずつの成分が認められ，2つ の運動が平行して実施されている事が同光る。 それに対して成功予想試行では大きな1つの準 備電位と小さな運動電位が認められ，パッティ ングに括ける運動の一貫性が認められた。この 事は, 多くのゴルファーが経験する事であるが, パッティング時に雑念がはいり，すなわちパッ ティング以外の動作あるいは思考が混在し集中 出来なかった。または，パッティング自体の動 作が一貫して行われずいくつかの，今回は2つ の，運動に分離されてしまった事を示している のではなかららか.

従来の研究では準備電位をはじめとする運動 関連電位は他の事象関連電位と同様に潜時, 部 位，極性の比較により幾つもの成分に分けられ て研究され，随意運動の前後にわたり計 8 成分 が報告されており ${ }^{19}$ 運動関連脳電位がさらに複 雑な構成であることが示唆されている，今回の 分析では導出部位や資料数が少ないため, 従来 報告されている程の多数の成分は見いだせな かった。また，成功予想で結果も成功あるいは， 失敗といらような細かな分析も出来なかった。

しかし，従来のよらに平均波形のみで検討する のとは全く異なる結果が得られたことは意義深 い.今後これらの成分の同定と，その機能的意 義を明確にする必要があると言えよう。

今後の運動に関連した電位の研究において は，被験者に親密な課題を用い，その電位成分 まで比較検討する事が必須であると思われる。

\section{文献 (References)}

1) Arezzo, J. and Vaughan, H.G. Jr. (1980) 
Intracortical sources and surface topography of the motor potential and somatosensory evoked potential in the monkey. In: Kornhuber, H.H. and Deecke, L. (Eds.) Progress in Brain Research 54 : Elsevier: Amsterdam. pp. 72-83.

2) Autret, A., Auvert, L., Laffont, F. and Larmande, P. (1985) Electroencephalographic spectral power and lateralized motor activities. Electroenceph. Clin. Neurophysiol. $60: 228-236$.

3) Brunia, C.H.M. and Vingerhoets, A.J.J.M. (1980) CNV and EMG preceding a plantar flexion of the foot. Biol. Psychol. 11: 181-191.

4) Deecke, L., Eisinger, H. and Kornhugur, H.H. (1980) Comparison of Bereitschafts-potential, pre-motion positivity and motor potential preceding voluntary flexion and extension movements in man. In : Kornhuber, H.H. and Deecke, L. (Eds.) Progress in Brain Research 54. Elsevier : Amsterdam. pp. 171-176.

5) Deecke, L., Heid, P.S. and Kornhuber, H.H. (1969) Distribution of readiness potential, premotor potential, and motor potential of the human cerebral cortex preceding voluntary finger movements. Exp. Brain Res. 7 : 158-168.

6) Gerbrandf, L.K., Goff, W.R. and Smith, D.B. (1973) Distribution of the human average movement potential. Electroenceph. Clin. Neurophysiol. 34 : $461-474$.

7) Gilden, L., Vaughan, H.G. Jr. and Costa, L.D. (1966) Summated human EEG potentials with voluntary movement. Electroenceph. Clin. Neurophysiol. 20 : $433-438$.

8) Gliner, J.A., Mihevic, P.M. and Horvth, S.M. (1983) Spectral analysis of electroencephalogram during percentual-moter learning. Biol. Psychol. $16: 1-13$.

9）後藤 平・安達敏彦・片山宗一（1973）䯣意運動に 先行するいわゆる準備電位と分析脳波，反応時間と の関係について，臨床脳波 $15: 470-477$.

10) Hink, R.F., Kohler, H., Deecke, L. and Kornhuber, H.H. (1982) Risk-taking and the human
Bereitschaftspotential. Electroenceph. Clin. Neurophysiol. $53: 361-373$.

11）平 伸二・中田美喜子・松田 俊・柿木昇治（1989） 事象图連電位（P3，CNV）を指標とした虚偽検出。 生理心理と精神生理 $7: 11-17$.

12）岩瀬勝彦（1974）準備電位と随意運動の速度。臨床 脳波 $16: 300-303$.

13) Kakigi, S., Matsuda, T. and Hagino, G. (1978) Factors affecting the resolution of contingent negative variation (CNV). Japanese Psychol. Res. 20 : 187-190.

14）松田 俊（1988）運動学習についての生理心理学的 検討。スポーツ心理学研究 $15: 23-28$.

15）松田 俊・中田美喜子（1989）SAS とFORTRAN に上る事象関連奄位成分の推定. 広島龟機大学研究 報告 $22: 123-129$.

16）松田 俊- 寺谷美兽子・柿木昇治（1980） CNV（随 伴陰性変動) の復㷌についての分析. 心理学研究 $51: 203-206$.

17）中田美喜子・柿木昇治（1989）CNV の主成分分析に よる電位同定一漢字情報処理過程の模討一。広島修 大論集 $29: 243-252$.

18) Rockstroh, B., Elbert, T. and Lutzenberger, W. (1982) The effects of slow cortical potentials on response speed. Psychophysiology $19: 211-217$.

19) Shibasaki, H., Barrett, G., Halliday, E. and Halliday, A.M. (1980) Components of the movement-related cortical potential and their scalp topography. Electroenceph. Clin. Neurophysiol. $49: 213-226$.

20) Taylor, M.J. (1978) Bereitschaftspotential during the acquisition of a skilled motor task. Electroen. ceph. Clin. Neurophysiol. $45: 568-576$.

21) Woodruff, D.S. (1975) Relationships among EEG alpha frequency, reaction time, and age: A biofeedback study. Psychophysiology 12: 673 -681 . 